\title{
EFEK SALEP EKSTRAK PINANG \\ TERHADAP LEVEL FIBROBLAST DAN KOLAGEN PADA PROSES PENYEMBUHAN LUKA
}

\author{
Ave Olivia Rahman ${ }^{1}$, Humaryanto ${ }^{2}$ \\ ${ }^{1}$ Bagian Farmakologi, Fakultas Kedokteran dan IImu Kesehatan Universitas Jambi \\ ${ }^{2}$ Bagian Bedah, Fakultas Kedokteran dan IImu Kesehatan Universitas Jambi \\ Correspondence : Ave Olivia Rahman, Letjen Soepraopto No 33 Telanaipura, Kota Jambi, Jambi \\ aveoliviarahman@unja.ac.id
}

\begin{abstract}
Background: Some plants, such as betel nuts (Areca catechu), is used as traditional antiseptic. Betel nut mash is applied on ulcus wound. Fibroblast and collagen are important factor in wound healing. Research objective : this study is to determine the effect of betel nuts extract on fibroblast and collagen level in full thickness wound healing processs. Methodology: this study used male rats Sprague dawney that randomly divided into 3 groups. Groups I received no treatment, groups II and III received areca catechu extracts with concentration 15\% and $30 \%$ respectively. There are 12 rats in each groups. The treatment is given every day without wound's debridement. Incision were made full thickness with diameter size $1,5 \mathrm{~cm}$, on right back skin was made by lidocain anesthesia subcutaneously. Wound area were measured every days. Termination of rats were done in day 7 and day 16 to histopathology assessment with Haematoxylin-Eosin stain for fibroblast and collagen level by semiqualitative score. Results: level of collagen were higher in group that received extract but level of fibroblast were lower than control group in histopathology of day 7th. Conclusion: Extract of betel nut increased level of collagen.
\end{abstract}

Keyword : areca catechu, betel nuts, wound, fibroblast, collagen, histopathology

\section{ABSTRAK}

Latar belakang : Beberapa tanaman digunakan sebagai antiseptik luka, salah satunya biji pinang untuk penyembuhan luka ulkus. Fibroblast dan kolagen merupakan salah satu faktor penting dalam penyembuhan luka. Tujuan : Penelitian ini bertujuan mengetahui efek ekstrak biji pinang terhadap level fibroblast dan kolagen pada proses penyembuhan luka full thickness Metode : Penelitian ini menggunakan tikus galur Sprague dawney jantan berusia 2-3 bulan dan telah mendapatkan persetujuan etik. Setelah aklimatisasi, tikus dibagi secara acak 
masing-masing 12 ekor dalam 3 kelompok, yaitu kelompok I tanpa perlakuan, kelompok II diberikan salep ekstrak biji pinang 15\%, kelompok III diberikan salep ekstrak biji pinang 30\%. Luka full thickness dibuat dengan diameter $1,5 \mathrm{~cm}$ di daerah punggung belakang bagian kanan dengan anestesi lidokain subkutan. Perlakuan dilakukan setiap hari tanpa debridemen luka. Luas luka diukur setiap hari. Terminasi dilakukan pada hari ke 7 dan 16 untuk pemeriksaan histopatologi jaringan luka dengan pengecatan Haematoxylin-Eosin. Skoring secara semikualitatif untuk menilai fibroblast dan kolagen. Hasil : Pada kelompok ekstrak pinang terdapat peningkatan level kolagen, akan tetapi tidak terjadi peningkatan level fibroblast pada hasil histopatologi luka kulit hari ke-7. Kesimpulan : terjadi peningkatan level kolagen pada pemberian ekstrak biji pinang.

Kata kunci : biji pinang, luka, histopatologi, fibroblast, kolagen

\section{PENDAHULUAN}

Luka pada kulit sering terjadi di kehidupan sehari-hari. Keadaan ini terjadi akibat suatu trauma baik trauma fisik, kimia, maupun suhu, yang menyebabkan terputusnya jaringan fungsional kulit. Proses penyembuhan luka sangat komplek dan fibroblast merupakan fakor penting dalam proses penyembuhan luka ${ }^{1}$.

Saat terjadi perdarahan akan terjadi aktivasi pembekuan darah yang terdiri dari fibrin dan fibronektin. Platelet akan mensekresi senyawa kemotaksis yang menyebabkan migrasi sel neutrofil dan makrofag. Sel inflamasi ini juga ikut mensekresi senyawa kemotaksis dan growth factor untuk fibroblast. Fase ini disebut fase inflamasi. Fase selanjutnya adalah fase proliferasi. Fibroblast akan berproliferasi dan mensekresi kolagen, terutama kolagen tipe III. Selain itu, fibroblast juga akan diaktifkan dan berdiferensiasi dengan mengekspresikan aSM actin dan menjadi miofibroblast. Miofibroblast diduga berperan dalam kontraksi luka ${ }^{1-3}$.
Fase terakhir penyembuhan luka adalah remodeling jaringan granulasi luka. Selama proses remodeling ini, enzim proteolitik matrix metalloptroeteinase (MMPs) dan tissue inhibitor of metallopreoteinases (TIMPs) mempunyai peranan penting. Pada fase ini sintesis ektraseluler matrik menurun dan kolagen tipe III akan digantikan oleh kolagen tipe I yang mempunyai daya renggang lebih besar 1,4. Miofibroblast akan mengalami apoptosis sehingga jumlahnya menurun. Apabila jumlah ataupun aktivitas miofibroblast tidak mengalami penurunan maka dapat terjadi peningkatan jaringan parut ${ }^{1,5}$.

Setiap fase penyembuhan luka berlangsung tumpang tindih. Fase inflamasi berlangsung dari hari ke-1 sampai ke-4, fase proliferasi berlangsung dari hari ke-2 sampai hari ke-14 dan fase remodeling berlangsung mulai hari ke-13 sampai hari ke-18 bahkan berbulanbulan ${ }^{3}$.

Pemberian antiseptik topikal pada luka bertujuan untuk mencegah infeksi sehingga dapat mempercepat proses penyembuhan 
luka. Pemberian antiseptik atau bahan herbal lainnya dapat mempengaruhi proses penyembuhan luka. Beberapa bahan herbal dapat digunakan sebagai antiseptik luka oleh sebagian masyarakat 6-8. Pinang digunakan sebagai obat tradisional pengobatan luka ulkus oleh masyarakat India. Penelitian Verma dkk, pemberian ointment $2 \%$ ekstrak pinang secara topical pada luka bakar di tikus mempercepat kontraksi luka dibandingkan kontrol ${ }^{9}(2)$.

Pinang merupakan tanaman yang banyak tumbuh di daerah Sumatera, khususnya Provinsi Jambi dan mempunyai potensi untuk dikembangkan sebagai obat antiseptik Penelitian ini bertujuan untuk mengeksplorasi efek biji pinang terhadap level fibroblast dan kolagen pada proses penyembuhan luka kulit full thickness saat fase proliferasi (hari ke-7) dan fase remodeling (hari ke-16)

\section{METODE}

Penelitian ini telah mendapatkan persetujuan dari Komisi Etik Fakultas Kedokteran dan IImu Kesehatan Universitas Jambi. Penelitian dilakukan di Laboratorium Biomedik Fakultas Kedokteran dan IImu Kesehatan Universitas Jambi, dari Juli sampai Agustus 2018.

Pembuatan ekstrak pinang diawali dengan pinang muda yang masih berwarna hijau diambil biji dan dikeringkan dalam oven suhu $70^{\circ} \mathrm{C}$ selama 24 jam. Biji pinang dihaluskan dan dimaserasi dengan ethanol $70 \%$ dengan perbandingan 1 : 10 selama 24 jam. Campuran tersebut disaring dengan kertas saring whatman 41 untuk mendapatkan filtrat.
Filtrat dikeringkan dalam rotary evaporator sehingga diperoleh ekstrak kental.

Pembuatan salep dilakukan dengan menggunakan vaselin base. Ekstrak pinang 15 gram dan 30 gram diencerkan dengan sedikit aquadest dan dicampurkan dengan vaselin sampai dengan 100 gram, sesuai kadar yang diinginkan yaitu $15 \%$ dan $30 \%$.

Penelitian ini menggunakan tikus galur Sprague dawney, jantan, usia 2-3 bulan, berat 150-200 gram. Setiap kelompok terdiri dari 12 ekor tikus. Luka sayat full thickness dibuat didaerah punggung kanan atas berdiameter $1,5 \mathrm{~cm}$ dengan menggunakan anestesi lidokain secara subkutan. Kelompok pertama (I) tanpa perlakuan, kelompok kedua (II) diberikan salep ekstrak pinang 15\% dan kelompok III diberikan salep ekstrak pinang $30 \%$. Perlakuan diberikan setiap hari tanpa dilakukan debridement luka. Masing-masing tikus ditempatkan dalam kandang terpisah, diperlakukan sesuai etika perawatan hewan coba dalam penelitian.

Area luka diukur setiap hari dengan menggunakan plastik transparan bermotif kotak-kotak. Luka dinyatakan sembuh apabila telah menutup sempurna. Durasi luka dihitung dari hari mulai dibuat luka sampai dengan luka telah menutup sempurna.

Pada hari ke-7, 6 ekor tikus diterminasi untuk dilakukan pengambilan jaringan luka hari ke7 dan pemeriksaan histopatologi. Enam ekor tikus sisanya diterminasi pada hari ke-16 untuk pengambilan jaringan luka hari ke-16. Pemeriksaan histopatologi menggunakan pewarnaan Haematoxillin Eosin (HE) dan 
dilakukan penilaian oleh Ahli Patologi Anatomi secara blind. Penilaian meliputi fibroblast dan kolagen dengan skoring $0=$ tidak ada, $1=$ minimal, $2=$ minimal DL/GT, 3 = sedang, $4=$ berat. $\quad(\mathrm{ST}=$ surrounding Tissue, $\mathrm{DL}=$ Demarcation Line, GT= Granulation Tissue) 10,11 .

\section{HASIL DAN PEMBAHASAN}

Perbandigan level fibroblast dan kolagen pada proses penyembuhan luka pada hari ke-7 antara kelompok perlakuan dan kontrol dapat dilihat pada tabel 1. Level fibroblast pada kelompok perlakuan dengan salep ekstak pinang 30\% lebih tinggi dibandingkan dengan kelompok perlakuan dengan salep ekstak pinang 15\%. Hal ini menunjukkan semakin besar kadar ekstrak pinang semakin besar level fibroblast. Akan tetapi, level kolagen pada kelompok ekstrak pinang 30\% dan 15\% tidak ada perbedaan.

Sedangkan pada kelompok kontrol yang tanpa diberikan perlakuan, level fibroblast lebih tinggi dibandingkan kelompok perlakuan, akan tetapi level kolagennya lebih rendah dibandingkan kelompok perlakuan. Hal ini menunjukkan bahwa ekstrak pinang tidak mempunyai pengaruh pada level fibroblast, dan kemungkinan mempunyai pengaruh terhadap sekresi kolagen oleh fibroblast pada saat fase proliferasi (hari ke-7)
Tabel 1 perbandingan level fibroblast dan kolagen antar kelompok pada hari ke-7

\begin{tabular}{|l|c|c|c|c|}
\hline \multirow{2}{*}{ Variabel } & \multicolumn{3}{|c|}{ Rerata skor hari ke-7 } & Nilai $p$ \\
\cline { 2 - 5 } & KI & KII & KIII & \\
\hline Fibroblast & $3,83 \pm 0,41$ & $3,50 \pm 0,55$ & $3,67 \pm 0,52$ & 0,492 \\
\hline Kolagen & $2,16 \pm 0,42$ & $2,33 \pm 0,52$ & $2,33 \pm 0,52$ & 0,770 \\
\hline
\end{tabular}

Uji Kruskal Wallis

Perbandingan level fibroblast dan kolagen pada proses penyembuhan luka pada hari ke16 antara kelompok perlakuan dan kontrol dapat dilihat pada tabel 2. Level fibroblast pada kelompok perlakuan dengan salep ekstak pinang $30 \%$ lebih rendah dibandingkan dengan kelompok perlakuan dengan salep ekstak pinang $15 \%$. Apabila dibandingkan level fibroblast hari ke-16 dengan hari ke-7, penurunan level fibroblast pada pada kelompok ekstrak pinang 30\% lebih besar daripada kelompok ekstrak pinang 15\%. Level kolagen pada kelompok ekstrak pinang $30 \%$ lebih rendah dibandingkan dengan kelompok ekstrak pinang $15 \%$

Sedangkan pada kelompok kontrol yang tanpa diberikan perlakuan, level fibroblast lebih tinggi dibandingkan kelompok perlakuan. Hal ini sesuai dengan hari ke-7 bahwa level fibroblast lebih tinggi dibandingkan kelompok perlakuan. Level kolagen tidak ada perbedaan dengan kelompok ekstrak pinang 15\%. Hal ini menunjukkan bahwa kemungkinan ekstrak pinang menyebabkan penurunan fibroblast dan jumlah kolagen pada fase remodelling luka. 
Tabel 2 perbandingan level fibroblast dan kolagen antar kelompok pada hari ke-16

\begin{tabular}{|l|l|l|l|l|}
\hline variabel & \multicolumn{2}{|l|}{ Rerata skor hari ke-16 } & Nilai $p$ \\
\hline & KI & KII & KII & \\
\hline fibroblast & $1,16 \pm 1,32$ & $1,00 \pm 1,09$ & $0,89 \pm 1,36$ & 0,159 \\
\hline kolagen & $3,50 \pm 0,55$ & $3,50 \pm 0,55$ & $3,17 \pm 0,75$ & 0,638 \\
\hline
\end{tabular}

Uji Kruskall Wallis
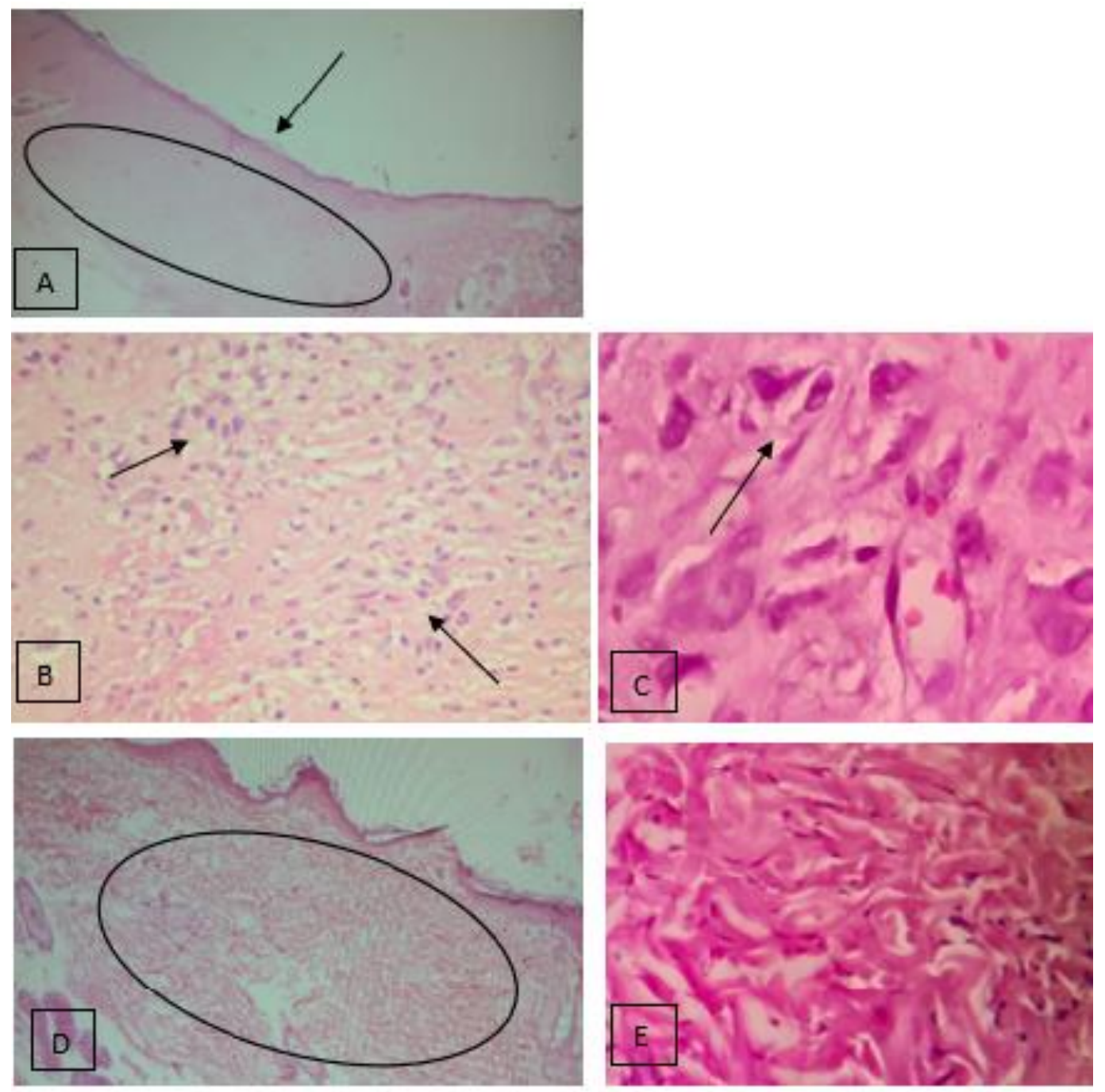

Gambar 1. Histopatologi jaringan luka kulit kelompok pinang. A: jaringan luka kulit hari ke-16 pembesaran 10x, area penyembuhan luka (lingkaran), penutupan luka telah lengkap terdapat epitelisasi (panah); B: jaringan luka kulit hari ke-7 pembesaran 10x, tampak fibroblast dan kolagen (panah); C: jaringan luka kulit hari ke-7 pembesaran 40x tampak fibroblast (panah); D : jaringan luka kulit hari ke-16 pembesaran 10x tampak kolagen (lingkaran); E : jaringan luka kulit hari ke-16 pembesaran 40 x tampak serat kolagen mulai tersusun. 
Biji pinang mengandung senyawa fitokimia yang bermanfaat bagi penyembuhan luka seperti antiokasidan, antiinflamasi dan antibakteri. Senyawa tersebut antara lain polyphenol, (20\%), lemak (15\%), serat (20\%) dan alkaloid. Polyphenol terutama adalah flavonols sedangkan alkaloid terutama adalah arecoline, arecaidine, guvacoline dan guvacine. Kandungan lemak antara lain lauric acid, myristic acid, palmitic acid dan lainnya ${ }^{12}$. Berdasarkan beberapa studi biji pinang dapat digunakan sebagai obat penyembuhan luka. Hasil uji invivo luka bakar pada tikus albino yang diinduksi dexametason sebagai obat penghambat penyembuhan luka menunjukkan bahwa pemberian ekstrak etanol biji pinang dapat meningkatkan kontraksi luka dan penutupan luka bakar ${ }^{9}$. Ekstrak biji pinang diketahui dapat meningkatkan sel fibroblast dan kolagen ${ }^{13}$.

Pada penelitian ini pengamatan penutupan luka selama 16 hari didapatkan hasil bahwa pemberian ekstrak pinang $15 \%$ ataupun $30 \%$ tidak mempercepat penutupan luka dibandingkan kontrol yang tidak diberikan perlakuan. Rata-rata penutupan luka pada hari ke-16 pengamatan pada kelompok ekstrak pinang $15 \%$ adalah $97 \%$, pada kelompok ekstrak pinang 30\% adalah 93\% dan kelompok kontrol adalah 99\% (data tidak ditampilkan). Hasil ini sesuai dengan hasil histopatologi jaringan luka kulit hari ke-7 dan 16 dimana didapatkan level fibroblast pada kelompok ekstak pinang lebih rendah dibandingkan kelompok kontrol.
Pada penelitian ini didapatkan hasil yang menarik yaitu kelompok ekstrak pinang mempunyai mempunyai level kolagen lebih tinggi dibandingkan dengan kontrol, walaupun perbedaannya tidak signifikan $(p>0,05)$. Padahal kelompok kontrol mempunyai level fibroblast lebih tinggi. Fungsi fibroblast adalah mensekresi kolagen. Akan tetapi, proses penyembuhan luka merupakan proses yang komplek yang melibatkan berbagai sel, faktor pertumbuhan dan enzim-enzim proteolitik yang memerlukan keseimbangan agar penyembuhan luka terjadi sempurna dan tidak timbul jaringan parut yang berlebihan $1,3,5$. Hal ini kemungkinan ekstrak pinang yang didapat meningkatkan sekresi kolagen. Peningkatan kadar level kolagen pada ekstrak pinang 15\% dan $30 \%$ tidak berbeda, kemungkinan dipengaruhi oleh daya absorpsi zat aktif.

Keterbatasan penelitian ini tidak dilakukan pemeriksaan senyawa aktif terhadap hasil ekstraksi sehingga tidak dapat mengukur hubungan konsentrasi ekstrak dengan level kolagen. Selain itu, pengecatan histopatologi dilakukan secara sederhana menggunakan haemaotxilin eosin dan skoring secara semikualitatif untuk penilaian level fibroblast dan kolagen.

\section{KESIMPULAN DAN SARAN}

Kesimpulan yang dapat diambil adalah hasil ekstrak biji pinang yang dilakukan pada penelitian ini menyebabkan peningkatan pada level kolagen tetapi tidak pada level fibroblast pada jaringan luka kulit full thickness tikus. Perlu dilakukan penelitian lebih lanjut 
mengenai zat aktif dalam ekstrak dan

pemeriksaan histopatologi secara kuantitatif

untuk mengukur level fibroblast dan kolagen.

\section{REFERENSI}

1. Darby IA, Laverdet B, Bonté F, Desmoulière A. Fibroblasts and myofibroblasts in wound healing. Clinal Cosmetic and Investigational Dermatology. 2014;7:301-11

2. Bainbridge P. Wound healing and the role of fibroblasts. Journal of Wound Care. 2013;22(8):407-12

3. Gonzalez AC de O, Costa TF, Andrade Z de A, Medrado ARAP. Wound Healing - A Literature Review. Anais Brasileiros de Dermatologia. 2016;91(5):614-620.

4. Xue M, Jackson CJ. Extracellular Matrix Reorganization During Wound Healing and Its Impact on Abnormal Scarring. Advances in Wound Care. 2015;4(3):119-36.

5. Darby IA, Hewitson TD. Fibroblast Differentiation in Wound Healing and Fibrosis. International Review of Cytology. 2007;257:143-79.

6. Yuwono HS. The New Paradigm of Wound Management Using Coffee Powder. Global Journal of Surgery. 2014;2(2):25-29.

7. Hosseinkhani A, Falahatzadeh M, Raoofi E, Zarshenas MM. An Evidence-Based Review on Wound Healing Herbal Remedies From Reports of Traditional Persian Medicine. Journal of Evidence-Based Complementary and Alternative Medicine. 2017;22(2):334-43.

8. Dorai A. Wound care with traditional, complementary and alternative medicine [Internet]. Vol. 45, Indian Journal of Plastic Surgery. 2012;45(2): 418.

9. Verma DK, Bharat M, Nayak D, Shanbhag T, Shanbhag V, Rajput RS. Areca catechu : Effect of topical ethanolic extract on burn wound healing in albino rats. International Journal of Pharmacology and Clinical Sciences. 2012;1(3):74-8.

10. Gupta A and Kumar P. Assessment of The Histological State of The Healing Wound. Plastic Aesthetic Research. 2015;2(5):239-242.

11. Udoh R, Agbo MO. Wound Healing Activity of N-Hexane and Methanol Extracts of Tetracarpidium Conophorum (Mull. Arg) Hutch (African Walnut) in Wistar Rats. Malaysian Pharm sci. 2014;12(1):7988.

12. Amudhan MS, Begum VH, Hebbar KB. A Review on Phytochemical and Pharmacological Potential of Arecha Catechu L. Seed. International Journal of Pharmceutical Sciences and Research. $2012 ; 3(11): 4151-7$

13. Lee K. The effects of Areca catechu $L$ extract on anti-aging. International Journal of Cosmetic Science. 1999;21: 285-95. 